Раздіна О. В.

\title{
КОНСЕРВАТИВНА ОЦІНКА ТЕРОРИЗМУ ЯК ФЕНОМЕНА ГЛОБАЛІЗАЦЇ̈ В РОБОТІ МАРГАРЕТ ТЕТЧЕР «МИСТЕЦТВО КЕРУВАННЯ ДЕРЖАВОЮ. СТРАТЕГІЇ ДЛЯ МІНЛИВОГО СВІТУ»
}

У статті досліджено динаміку політичних трансформаџій, викликану сучасними прочесами глобалізації, у роботі М. Тетчер. Розглянуто проблеми тероризму в контексті сучасного дискурсу та консервативної теоріі. Визначено прочеси утворення сучасного світового устрою.

Ключові слова: глобалізація, консерватизм, світовий устрій, тероризм.

The article analyzes the dynamics of political transformation caused by modern processes of globalization in M. Thatcher's work. The problems of terrorism in the context of contemporary discourse and conservative theory are considered. The processes of formation of the modern world order are identified.

Keywords: globalization, conservatism, world order, terrorism.

Дослідження світової політики Маргарет Тетчер не випадково вважають одним iз найбільш послідовних i значних із огляду на системність i аргументованість, а також вагомим внеском в обгрунтування актуальності консерватизму як комплексу принципів оцінювання практики державного керування й похідної від неї новітньої всесвітньої історії. Погляди М. Тетчер як одного з найбільш впливових керівників великої держави Свропи XX ст. на переломний період історії відбили проблеми війни і миру та ролі держави в забезпеченні міжнародної безпеки через призму глобалізації як визнаного автором джерела виникнення й трансформації більшості феноменів світового політичного процесу та втілилися в стратегії керування державою в мінливому світі як результат наукової праці. У монографії «Мистецтво керування державою. Стратегії для мінливого світу» розроблено тезу про можливість створення й утілення політичних стратегій, суб'єктом яких є держава, здатна реалізувати себе в умовах безперервних змін конфігурації світового порядку і його ієрархії й базових факторів зовнішньої й внутрішньої політики в системі міжнародних відносин навіть за загострення міжнародних конфліктів. Тут із позицій комплексу ідей консерватизму й неоконсерватизму подано аналіз теорії й практики державного керування в сучасному світі, що охоплює підсумки «холодної війни», роль США як наддержави й світового лідера, європейські й азіатські досягнення й цінності, світові конфлікти, роль національної держави й аномалії її сучасного розвитку, тероризм, роль релігії й права людини. Видається актуальним на підставі аналізу цієї роботи провести дослідження глобальних тенденцій зміни конфігурації сучасних інститутів політичної влади й похідних від них процесів виникнення й прояву тероризму. Вони становлять відповідно об'єкт розгляду й предмет пропонованої статті.

У досліджуваній роботі вихідною тезою аналізу послужили проблеми 
глобалізації й регіоналізації як основні тенденції світового розвитку теперішнього часу. «Початок XXI століття має свої особливості, що визначають зміст мистецтва керування державою в наші дні, які можна виразити одним словом - “глобалізація"» [1, с. 15-16] Автор бачить у глобалізації чинник більшості трансформацій феноменів локального й загальносвітового значення 3 особливим значенням у цьому процесі економічних факторів розвитку глобалізації як породження капіталізму [1, с. 443499]. «...Глобалізація - явище не нове. Глобальні проблеми існували й раніше наприкінці XIX i на початку XX століття... Частка світової продукції, продана на глобальних ринках, у наш час не набагато більша, ніж була напередодні Першої світової війни. Багато країн уже тоді відкрили свої ринки капіталу... Наприкінці ХІХ сторіччя... чинниками економічної глобалізації були технічні й політичні фактори. Транспортні витрати знизилися, а час доставки було скорочено в результаті освоєння енергії пару... До кінця сторіччя увесь світ був зв'язаний телеграфними лініями, що стало початком міжнародної телекомунікаційної революції. В основі цього лежала вільна торгівля, двигуном якої із середини XIX сторіччя була Великобританія, а в більш широкому розумінні - зростання європейських колоніальних імперій, особливо Британської, що втягувала в глобальну політичну й економічну мережу тією чи іншою мірою всі континенти. Поновлення процесу глобалізації наприкінці XX сторіччя було також зумовлене технічними й політичними факторами, однак роль останніх відносно вища... Друга істина... у тім, що вплив у жодному разі не $\epsilon$ загальним. Я зовсім не маю на увазі власне слабкорозвинені країни, де значна частина населення живе «із землі», займаючись нетоварним сільськогосподарським виробництвом. На гнітючу частину економічної діяльності й робочих місць навіть у найбільш багатих країнах тенденції на глобальних ринках не чинять прямого впливу» [1, с. 491-493]. Таким чином, неухильна траєкторія руху світової економіки 3 наступним відбиттям економічних перетворень у політику - головним чином у зростання значення імперії як моделі організації політичного простору, що глобалізується, - визначена роллю технічних i технологічних, транспортних i товарних факторів розвитку процесів глобалізації, що показано ретроспективним аналізом. Економічна складова глобалізації виявилася рушійною силою й «локомотивом» «міжнародної телекомунікаційної революції» переходу до революційних змін у світових тенденціях політики. Консерватизм заперечує конструктивність революцій, однак тут М. Тетчер відзначає революції як засіб i фактор глобалізаційних трансформацій за допомогою комунікаційної (транспорт, зв'язок і ринок) та інформаційної складових, хоча вплив усіх цих факторів і «не $\epsilon$ загальним», - він є різним для «слабкорозвинених країн» із «нетоварним сільськогосподарським виробництвом» «населення» й для «найбільш багатих країн», на які «навіть... тенденції на глобальних ринках не чинять прямого впливу». Із цього треба зробити висновок, що сучасна біфуркація світового розвитку може бути джерелом його суперечностей і рушійною силою подальших докорінних змін, але не ознакою загального революційного прориву до загального ж добробуту й процвітання. При цьому чинники цієї біфуркації й невідворотної як глобалізація перспективи збереження багатьма країнами статусу «слабкорозвинених» бачаться 


\section{Раздіна О. В. КОНСЕРВАТИВНА ОЦІНКА ТЕРОРИЗМУ ЯК ФЕНОМЕН ГЛОБАЛІЗАЦІЇ В РОБОТІ МАРГАРЕТ ТЕТЧЕР «МИСТЕЦТВО КЕРУВАННЯ ДЕРЖАВОЮ. СТРАТЕГІЇ ДЛЯ МІНЛИВОГО СВІТУ»}

авторові аж ніяк не в капіталізмі як засобі організації господарства. Навпаки, саме тут стратегічне керування може стати запорукою загального процвітання в повній відповідності до консервативної ідеї первинності політики й неоконсервативної ідеї «світової держави» як умови загального процвітання й стабільності. I на тлі не раз відзначуваного М. Тетчер як неминучого історичного підсумку краху «непримиренного комунізму» [1, с. 240] досконалість капіталізму демонструють перемога США в «холодній війні» та створення Європейського союзу. М. Тетчер стверджує, що саме називані для стислості «Заходом» США припинили «холодну війну». Ї̈ї результат як перемогу Заходу визначили забезпечені економічними можливостями технологічна й військова перевага Заходу, проголошені консерватором-президентом США Рейганом у вигляді програми COI, якій СРСР було нічого протиставити. Засноване на капіталістичній системі господарювання й цінностей світове лідерство США М. Тетчер уважає найкращим прикладом успішності капіталізму й запорукою стабільності сучасного світового порядку [1, c. 25-42]. Результатом же успіху національних стратегій із держав Свропи став Європейський Союз - новітня модель держави, що претендує на значення й статус наддержави на тлі зникнення СРСР. Тим самим відзначено, що хоча в досягнутих параметрах форми й змісту ЄС не $€$ успішним [1, с. 351-390], глобалізація $€$ продуктивною для процвітання в єднанні.

Як відзначає М. Тетчер, на зміну «абсолютним монархіям XVII й XVIII століть», що започатковують капіталізм через «революційні війни», «протиборство європейських імперій і націоналізм XX століття» й навіть «демократичні концепції держави загального добробуту XX століття», уже до початку XXI століття «зміст мистецтва керування державою» визначався «особливостями», «які можна відтворити одним словом - “глобалізація"» [1, с. 15-16]. Уважати глобалізацію «кінцем держави», а не «лише до деякої міри» «обмеженням» іiї влади - є «оманою». У «світі рухливого капіталу, міжнародної ринкової інтеграції, безпосередніх зв’язків, інформації... відкритих кордонів», африканських держав, «що занурені в злодійстві», i європейських 3 «надмірно високими податками й твердим регулюванням» «недосконала політика завдає шкоди тим, хто іï проводить» [1, с. 16]. «Держави зберігають своє значення... тому, що саме вони встановлюють правові межі, а розумна правова основа має колосальне значення (зараз, можливо, більше, ніж будь-коли) як для суспільства, так і для економіки... І... лише держави мають монопольне право на примус, тобто право придушення злочинності на власній території й захисту від зовнішньої загрози. Функцію примусу держава не повинна віддавати ніколи...» [1, с. 16-17]. Ця монополія стала особливо важлива після «терористичного акту 11 вересня 2001 року в США» - «дня, що змінив світ», - у «світі ризику, конфліктів і прихованого насильства», де «після перемоги над головним ворогом - радянським комунізмом» у «холодній війні» 3'явилася «необхідність глобальної війни проти тероризму» [1, с. 17-22]. Це причина «особливої уваги» М. Тетчер до «роли держав у забезпеченні міжнародної безпеки» в умовах «практично повного зосередження політиків на внутрішніх проблемах», коли спроби «домогтися бажаних результатів у міжнародних справах, не спираючись на силу,.. приречені на невдачу» [1, с. 17]. 
«Питання війни й миру» в уникненні «багаторічних ілюзій» відсутності «інших ворогів» після перемоги над комунізмом і очікуванні навік «тихого благополуччя» й «добросусідства» не уявляються М.Тетчер нерозв'язними. «Віддаючи пріоритет розгрому тероризму (це необхідно зробити зараз), ми... повинні прийти до іншого балансу між свободою особи й безпекою суспільства у своїй країні... При створенні коаліції для боротьби із загальним ворогом нам, можливо, доведеться, принаймні тимчасово, зблизитися 3 режимами, що не задовольняють нас, які в іншій ситуації були 6 для нас об'єктами критики» [1, с. 22].

Уважаючи тероризм головною проблемою, що вимагає негайного глобального вирішення, М. Тетчер аналізує цей феномен, як Макіавелі - владу, тобто не надаючи визначень і розглядаючи його зміст через специфіку причинно-наслідкових умов $\mathrm{i}$ факторів системного значення. Неодноразово повертаючись до неминучої проблеми тероризму в алгоритмах практичної політики як основної загрози й фактичної небезпеки масштабів, що не можна збагнути, М. Тетчер називає присвячений ій розділ «Держави-вигнанці, релігії й тероризм», підкреслюючи тим самим несамостійність феномена тероризму, його залежність від більш значних умов $\mathrm{i}$ підпорядкованість вирішальним факторам впливу основних інститутів. Зв'язок трьох об'єднаних феноменів автор розкриває з перших рядків розділу. «Держави-вигнанці, релігійний екстремізм і міжнародний тероризм - ці три поняття після 11 вересня 2001 року нерозривно переплелися один із одним в очах громадськості. Кожне із цих явищ вже саме по собі несе погрозу громадському миру й міжнародної стабільності. Спільне ж зло, що виходить від них, набагато перевершує просту суму його складових частин» [1, с. 237]. Вихідним феноменом і базовим для розгляду тероризму поняттям М. Тетчер уважає держав-вигнанців, відзначаючи, що пальма першості в постановці питання належить не їй. У 1990 р. концепція «нового світового порядку» президента США Буша, виходячи з тези Фукуями про «кінець історії», запропонувала сформувати у зв'язку із закінченням «холодної війни» «глобальне співтовариство високоорганізованих, що тісно співробітничають, $\epsilon$ відкритими й перебувають попереду всього демократичних держав», яке залишає «за межами їх кола, що постійно розширюється», «невелику кількість лиходіїв або “вигнанців”». Офіційне поняття «держави-вигнанці» вперше пролунало в 1993 р. у концепції зовнішньої політики США президента Клінтона, де була подана «стратегія розширення світового вільного співтовариства демократичних країн із ринковою економікою», що припускає «дипломатичну, військову, економічну й технологічну ізоляцію» державвигнанців. Малося на увазі, що «передова більшість, що мобілізується за рішенням Ради Безпеки ООН, здатна зірвати їхні наміри, стримати, ізолювати й, в остаточному підсумку, придушить їх» [1, с. 237-238]. М. Тетчер відзначає своє використання поняття «держави-вигнанці» «для позначення порівняно невеликих держав, які мають мотиви й засоби для створення неспіввимірно серйозних проблем» і називає «два припущення» як «неправильні» підстави конкретизації поняття за його вихідної «невизначеності» як «недоліку» [1, с. 238]. «Перше... всі «не вигнанці» зацікавлені один в одному настільки сильно, що це гарантує співробітництво між ними. Друге... один вигнанець як дві краплі води схожий на другого. Обидва припущення насправді 


\section{Раздіна О. В. КОНСЕРВАТИВНА ОЦІНКА ТЕРОРИЗМУ ЯК ФЕНОМЕН ГЛОБАЛІЗАЦЇ̈ В РОБОТІ МАРГАРЕТ ТЕТЧЕР «МИСТЕЦТВО КЕРУВАННЯ ДЕРЖАВОЮ. СТРАТЕГІЇ ДЛЯ МІНЛИВОГО СВІТУ»}

неправильні. Країни-вигнанці ніколи не бувають такими відчуженими, якими їх намагаються подати. Сдине, чим вони відрізняються від інших, так це здатністю завдавати шкоду або принаймні створювати загрозу іiі заподіяння через те, що користуються таємною підтримкою (що звичайно виражається в переданні технологій) із боку однієї або кількох великих держав, які входять до глобального магічного кола “гарних хлопців". Крім того, окремі держави, що вважаються “вигнанцями”, нерідко мають зовсім різні пріоритети й можливості» [1, с. 238-239]. Але загроза заподіяння шкоди, а тим більше за якогось таємного сприяння, i $\epsilon$ вказівкою на ознаки тероризму, тобто визначення тероризму є, тільки з вказівкою на суб’ єкти-носії ознак і «здатності» й «можливості» в них відбутися.

М. Тетчер відзначає, що «зазвичай до списку держав-вигнанців потрапляють Північна Корея, Ірак, Сирія, Ліван і (меншою мірою) Судан» за ознаками недемократичності, відсутності «керування за законом», «переслідування дисидентів і опозиційних груп», «принципової ворожості до Заходу» й «володіння зброєю масового знищення» [1, с. 239]. При цьому «атеїстичні ідеології, не підкріплені примусом, відступають перед релігійними віруваннями» [1, с. 247]. В ісламі М. Тетчер «захоплює міцність сімейних уз, нетерпимість до антисоціальної поведінки, низький... рівень злочинів проти особистості й почуття відповідальності щодо бідних», але «існує й інший бік... що проявляє себе в корупції й лицемірстві деяких із тих, хто є при владі, у гнобленні жінок, у жорстокості деяких традицій, зокрема покарань, а також в убогості й відсталості багатьох міст Близького Сходу» [1, c. 247-248]. «У виразі... “ісламський тероризм”... є щось неправильне. Тероризм не можна аналізувати й, в остаточному підсумку, боротися 3 ним, виходячи 3 його "мотивів" - релігійних або світських, політичних або економічних, соціальних або етнічних. Існує безліч визначень тероризму. Але в кожному разі боятися й ненавидіти терористів змушують методи, що припускають насильство, а не причини й виправдання. Терорист намагається домогтися свого не просто за допомогою насильства, а за допомогою страху перед насильством. Він хоче залякати не менше, ніж убити й заподіяти каліцтво. Його метою тому побічно, а нерідко й прямо, $є$ цивільне населення. Насильство в цьому випадку завжди застосовується не перебираючи. У тероризму немає ніяких обмежень, оскільки він не визнає ні національних законів, ні міжнародних обмежень, ні норм моралі. Тероризм... насильство, спрямоване проти тисяч безневинних людей, можна в такий спосіб уважати абсолютним» [1, с. 248-249].

Таким чином, зумовлена біфуркацією глобалізації дистанція в розвитку держав і політико-економічні, підкріплені технологіями особливості «держав-вигнанців» створюють для тероризму можливість ігнорувати закони й мораль для застосування абсолютного насильства.

\section{Література:}

1. Тэтчер М. Искусство управления государством. Стратегии для меняющегося мира / пер. с англ. М. : Альпина Паблишер, 2003. 504 с. 


\section{References:}

1. Tetcher, M. (2003), Iskusstvo upravleniya gosudarstvom. Strategii dlya menyayushchegosya mira [The Art of State Administration. Strategies for a changing world], Al'pina Pablisher, Moscow, 504 p.

\section{Olena Razdina}

\section{CONSERVATIVE EVALUATION OF TERRORISM AS THE GLOBALIZATION PHENOMENON IN «STATECRAFT: STRATEGIES FOR A CHANGING WORLD» BY MARGARET THATCHER}

Margaret Thatcher's artistic heritage is one of the most vivid manifestations of topicality of conservative movement as the modern evaluation system of the world political reality. The conservative and later neoconservative ideological complexes were developed with maximum accuracy for the latest world reality in the perspective and retrospective.

Margaret Thatcher's research object and conservative evaluation object are very broad systemically and include the questions of the "Cold War» evaluation, the role of the USA as the superpower and world leader, the Asia and Europe achievements and values, the world conflicts, the role of modern national state and the anomaly of state development, terrorism, religion and human rights.

Margaret Thatcher takes into account the fact that globalization and regionalization problems are basic questions and most important tendencies of the world development. Margaret Thatcher's evaluation is entirely conservative and at the same time somewhat emotional, it corresponds to ideological conviction if it is dictated by the reality and the productivity of idea.

In the part of retrospective analysis of the theory Margaret Thatcher underlines the role of technical and technological revolution in political and economic world development and the role of empire as a forming factor of world globalization model of political space organization. This model was used for British Empire expansion.

Margaret Thatcher doesn't exaggerate the significance of economic factors for the formation of globalization processes, their current and perspective conditions. The economic part of world development processes became a driving force and the «locomotive» of the world history of telecommunicate revolution. After the achievement of triumph by these tendencies the economic globalization processes gave way to political ones as the most important ones. Conservatives consider political processes to be system organizing and system transforming factors under any condition. Probably the complex and systemic evaluation of the globalization processes by conservatism doctrine is adjusted by the marginal modifications of world political space changes. Conservative research takes into consideration the meaning and character of changes of world political space or any fragment of this space for working out the most accurate estimate.

Margaret Thatcher notes the bifurcation of world development in the period of formation of new tendencies and affirms that it is a new source of antagonisms as a driving force of further development. At the same time the ambiguity of economic role of globalization cannot be reduced to the indiscriminate capitalism criticism. Capitalism is not 


\section{Раздіна О. В. КОНСЕРВАТИВНА ОЦІНКА ТЕРОРИЗМУ ЯК ФЕНОМЕН ГЛОБАЛІЗАЦІЇ В РОБОТІ МАРГАРЕТ ТЕТЧЕР «МИСТЕЦТВО КЕРУВАННЯ ДЕРЖАВОЮ. СТРАТЕГІЇ ДЛЯ МІНЛИВОГО СВІТУ»}

criticized as the way of production and the way of organization of global economy. On the contrary, capitalism as any other world economy organization model is a benefit if it is based on the strategic government management. However, capitalistic bifurcation of world economy development demonstrates the rightfulness of neoconservative idea of «world power» importance in newest modern realities. Systematic and invariable success of states using this system of economic and political values, such as the USA, is the example. So, in this context globalization processes determine the nature of world order and represent driving forces and factors of its further development and possible transformation in the conditions of changing globalization nature.

Margaret Thatcher summarizes the globalization meaning and notes the necessity to glorify the triumph of global capitalism based on the free business activity, though shocks are inevitable. Margaret Thatcher also considers important actions aimed at making the profits from free trade accessible to all states in the world. The terrorism is a main problem of modern policy.

Thus, the conservatism in Margaret Thatcher's work appears as one of the most promising socio-political movements of modern world. The conservatism, as Margaret Thatcher summarizes, is able to explain the most difficult phenomena and contradictions of political reality and to suggest really promising political models and ideals.

Keywords: globalization, conservatism, world order, terrorism.

\section{олена Раздіна}

\section{КОНСЕРВАТИВНА ОЦІНА ТЕРОРИЗМУ ЯК ФЕНОМЕНА ГЛОБАЛІЗАЦЇ̈ В РОБОТІ МАРГАРЕТ ТЕТЧЕР «МИСТЕЦТВО КЕРУВАННЯ ДЕРЖАВОЮ. СТРАТЕГІЇ ДЛЯ МІНЛИВОГО СВІТУ»}

Творча спадщина Маргарет Тетчер є одним із найбільш яскравих проявів актуальності консерватизму як сучасної системи оцінювання світової політичної реальності. Консервативний і більш пізній неоконсервативний ідейні комплекси розроблені з максимальною точністю для новітньої світової дійсності в перспективі й ретроспективі.

Науковий об'єкт і об'єкт консервативного оцінювання Маргарет Тетчер є дуже системно широкими й охоплюють питання «холодної війни», ролі США як наддержави й світового лідера, європейських і азіатських досягнень і цінностей, світових конфліктів, ролі сучасної національної держави й аномалії розвитку держави, тероризму, релігії й прав людини.

Маргарет Тетчер бере до уваги, що проблеми глобалізації й регіоналізації $\epsilon$ основними питаннями й найбільш важливими тенденціями світового розвитку. Оцінка Маргарет Тетчер є цілком консервативною й разом із тим трохи емоційною та відповідає ідеологічній переконаності, якщо це продиктовано дійсністю або продуктивністю ідей.

У частині ретроспективного аналізу теорії Маргарет Тетчер підкреслює роль технічної й технологічної революцій у політичному й економічному світовому 
розвитку й роль імперій як фактору формування світової глобалізованої моделі організації політичного простору. Ця модель була використана для поширення Британської імперії.

Маргарет Тетчер не перебільшує значення економічних факторів у формуванні процесів глобалізації сучасного й перспективного їхнього стану. Економічна частина процесів світового розвитку виявилася рушійною силою й «локомотивом» історії світової телекомунікаційної революції. Після настання тріумфу цих тенденцій процеси економічної глобалізації поступилися вирішальному значенню політичних як найбільш важливих. Політичні процеси є для консерваторів за будь-яких обставин системоутворювальними й системоперетворювальними факторами. Імовірно, комплексна й системна оцінка доктриною консерватизму процесів глобалізації коректується граничними модифікаціями зміни світового політичного простору. Консервативне дослідження враховує значення й характер змін світового політичного простору або будь-якого його фрагмента для вироблення найбільш точної оцінки.

Маргарет Тетчер відзначає біфуркацію світового розвитку в період формування нових тенденцій і стверджує, що це є новим джерелом суперечностей як рушійної сили подальшого розвитку. У той же час неоднозначність економічної ролі глобалізації не зводиться до огульної критики капіталізму. Капіталізм не є предметом критики як засіб виробництва й організації світового господарства. Навпаки, капіталізм як будь-яка модель організації світового господарства є благом, якщо він грунтується на стратегічному державному керуванні. Разом із тим капіталістична біфуркація світового економічного розвитку демонструє правоту неоконсервативної ідеї важливості «світової держави» в сучасних новітніх реаліях. Системний i незмінний успіх держав, що використовують цю систему економічних і політичних цінностей, $є$ прикладом. Успіх США становить головний приклад. І в цьому контексті глобалізаційні процеси визначають характер світового порядку й становлять рушійні сили й фактори його подальшого розвитку й можливої трансформації в умовах зміни характеру глобалізації. Тероризм є головною проблемою сучасності.

Маргарет Тетчер резюмує значення глобалізації й відзначає необхідність прославляти перемогу глобального капіталізму, що грунтується на вільному підприємництві, але потрясіння неминучі. Також Маргарет Тетчер вважає за необхідне діяти, щоб вигоди від вільної торгівлі стали доступними для всіх держав у світі.

Таким чином, консерватизм у творчості Маргарет Тетчер виявляється однією iз найбільш перспективних соціально-політичних течій сучасного світу. Консерватизм, резюмує Маргарет Тетчер, здатний пояснити найбільш складні феномени й суперечності політичної дійсності та запропонувати дійсно перспективні політичні моделі й ідеали.

Ключові слова: глобалізачія, консерватизм, світовий устрій, тероризм.

Razdina Olena - Ph.D. in Economy Science, Associate Professor, Associate Professor of the Department of Law Faculty of Humanities of the National Aerospace University «Kharkiv Aviation Institute». 
Раздіна Олена - кандидат економічних наук, доцент, доцент кафедри права гуманітарного факультету Національного аерокосмічного університету ім. М. Є. Жуковського «Харківський авіаційний інститут».

Надійшла до редакції 06.03.2019. Розглянута на редколегії 27.08.2019.

\section{Рецензенти:}

Кандидат політичних наук, доцент, доцент кафедри права гуманітарного факультету Національного аерокосмічного університету ім. М. Є. Жуковського «XAI» Ковальова I. I.

Кандидат юридичних наук, доцент, доцент кафедри права гуманітарного факультету Національного аерокосмічного університету ім. М. Є. Жуковського «Харківський авіаційний інститут» Гуцу С. Ф. 